TÜRK JINEKOLOJIK ONKOLOJI DERGISI

2017-2, Sayfa 23-26

Olgu Sunumu

\section{A Case of Uterine Tumor Resembling Ovarian Sex Cord Tumor Treated with Uterine Wedge Resection}

\section{Uterin Kama Rezeksiyonu ile Tedavi Edilen Overin Seks Kord Tümörüne Benzeyen Uterin Tümör Vakası}

\author{
Duygu Altın', Salih Taşkın², Fırat Ortaç²
}

\title{
ÖZET
}

Amaç: Amaç: Overin seks kord tümörüne benzeyen uterin tümör (OSKTBUT) nadir görülen bir uterus tümörüdür. Patolojik olarak daha agresif seyreden ve sağ kalımı daha kötü olan seks kord elemanları olan endometrial stromal tümörlerden ayrılmalıdır. Histerektomi \pm ooferektomi tercih edilen tedavi şekli olsa da son yıllarda genç hastalarda fertilite koruyucu cerrahi uygulanmaya başlanmıştır. Tümörün histeroskopik rezeksiyonu en sık uygulanan yaklaşımdır. Bildiğimiz kadarıyla bu olgu uterin kama rezeksiyonu ile tedavi edilen ilk OSKTBUT vakasıdır.

Olgu: 26 yaşında, nulligravid, menometroraji şikayeti ile başvuran hastada $4 \mathrm{~cm}$ submüköz myom tespit edilmiştir. Abdominal myomektomi yapılan hastanın patoloji sonucu OSKTBUT olarak raporlanmıştır. Kontrol ultrasonografi ve PET/BT'sinde uterusta şüpheli lezyon saptanan hastaya uterin kama rexeksiyonu yapılmış ve temiz cerrahi sınır elde edilmiştir. Hasta 6 yıldır hastalıksız takip edilmektedir.

Tartışma: OSKTBUT genelde ileri yaşta görülmektedir. Tümörün düşük malignite potansiyeli olduğundan genç, fertilite isteği olan hastalarda uterus koruyucu cerrahi uygulanabilmektedir. Fertilite koruyucu yaklaşımların güvenilirliğini ve sonuçlarını desteklemek için daha fazla vakaya ihtiyaç vardır.

Anahtar sözcükler: Overin seks kord tümörüne benzeyen uterin tümör, fertilite koruyucu cerrahi

\section{ABSTRACT}

Introduction: Uterine tumor resembling ovarian sex cord tumors (UTROSCT) are infrequent forms of uterine tumors. It should be distinguished from endometrial stromal tumors with sex cord like elements (ESTSCLE) since the latter one is more aggressive and the outcome is poorer. Hysterectomy with or without adnexectomy is the preferred choice of treatment. Fertility preserving treatment options are seen more commonly in the last decade for young patients. Hysteroscopic resection of the tumor is the most frequent approach. To our knowledge this is the first case of UTROSCT who was treated with uterine wedge resection.

Case: We describe here a case of 26-year-old nulligravid woman with menometrorrhagia whose ultrasonographic examination revealed $4 \mathrm{~cm}$ submucous myoma. Abdominal myomectomy was done but the pathological result was UTROSCT. An abnormal lesion was detected in her control ultrasonography and PET/CT. She then underwent uterine wedge resection with clear surgical margins. She is being followed up for 6 years with no evidence of disease.

Discussion: UTROSCT is usually seen in elderly women. Conservative management can be an option for younger women who have fertility desire. It seems like it is an acceptable choice since the tumor has low malignant potential. More cases are needed to support the safety of fertility preserving treatment and the outcome.

Keywords: Uterine tumors resembling ovarian sex cord tumors, fertility preservation

Geliş Tarihi: 19/02/2018 Kabul Tarihi: 20/10/2018

'iDuygu Altın, Salih Taşkın², Fırat Ortaç²

Ankara University School of Medicine, Department of Obstetrics and Gynecology

Corresponding Author: Dr. Duygu Altın

Ankara University School of Medicine Department of Gynecology and Obstetrics

06620, Cebeci, Ankara, TURKEY

Phone: +90 3125956839 , +90 5356766125

E-mail: duyguo@ada.net.tr 


\section{Introduction}

Uterine tumor resembling ovarian sex cord tumors (UTROSCT) are infrequent forms of uterine tumors. It should be distinguished from endometrial stromal tumors with sex cord like elements (ESTSCLE) since the latter one is more aggressive and the outcome is poorer. These two tumors were distinguished by Clement and Scully in 1976 after it was first described by Morehead and Bowman in 1945 (1). The World Health Organization defines UTROSCT as miscellaneous tumors and ESTSCLE as a rare variant of endometrial stromal tumors. Hysterectomy with or without adnexectomy is the preferred choice of treatment. Fertility preserving treatment options are seen more commonly in the last decade for young patients since these tumors have low malignant potential (2). Hysteroscopic resection of the tumor is the most frequent approach. To our knowledge this is the first case of UTROSCT who was treated with uterine wedge resection.

\section{Case}

A 26-year-old nulligravid woman presented with menometrorrhagia to a different hospital. She had no remarkable medical history. Ultrasound examination revealed $4 \mathrm{~cm}$ submucous myoma at uterine fundus. Abdominal myomectomy was performed. Unfortunately, pathological examination revealed uterine tumor resembling ovarian sex cord tumor. The tumor was yellow macroscopically and characterized by epitheloid cylindrical cells in solid architecture which resembled sex cord stromal tumors of ovary (Figure 1). Immunohistochemistry showed positive staining with calretinin, CD99, vimentin and AE1/AE3 cytokeratins
(Figure 2). Since the pathological result was UTROSCT, she was then referred to our hospital. A $12 \mathrm{~mm}$ lesion was detected at uterine fundus in ultrasonography. In PET/CT, the same lesion had also pathological uptake (SUVmax:3.9). She then underwent uterine wedge resection with clear surgical margins. No adjuvant treatment was given and she had regular surveillance visits. She is being followed up for 6 years with no evidence of disease.

\section{Discussion}

UTROSCT is usually seen in elderly women. The mean age at the time of diagnosis is $52.2 \pm 18.2$ years (3). Although it can be asymptomatic, patients usually present with abnormal vaginal bleeding followed by pelvic pain (4). Preoperative diagnosis is difficult since it mimics endometrial polyp or myoma uteri in ultrasound and most of the patients were operated with these presumed diagnoses. UTROSCT is usually diagnosed postoperatively with histomorphologic features and immunohistochemistry study. Most of the patients are treated with hysterectomy with or without adnexectomy. Since these tumors are of low malignant potential, no further treatment is given usually and patients are followed up regularly with diagnostic imaging modalities.

Fertility sparing surgery for young patients had been reported by some authors $(2,3,5,6)$. Most of them are done by resectoscope and some by abdominal myomectomy. 5 patients were able to conceive after fertility sparing surgery and 3 of them delivered healthy babies $(2,3,5)$. Pregnancy outcomes of other two patients couldn't be obtained. One of these patients was even able to conceive after the second uterus sparing surgery due to recurrence of UTROSCT (2).
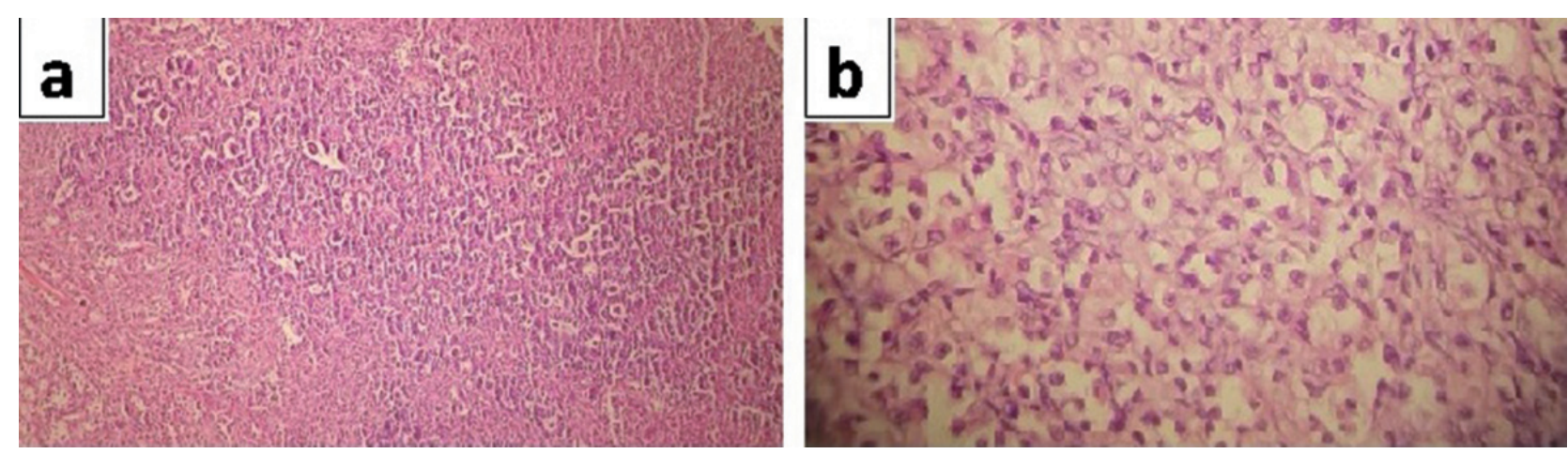

Figure 1. Granulosa-like neoplastic cells forming tubules and on right side area with retiform pattern (H\&E,10x). b. Foamy cell groups $(\mathrm{H} \& \mathrm{E}, 20 \mathrm{x})$. 

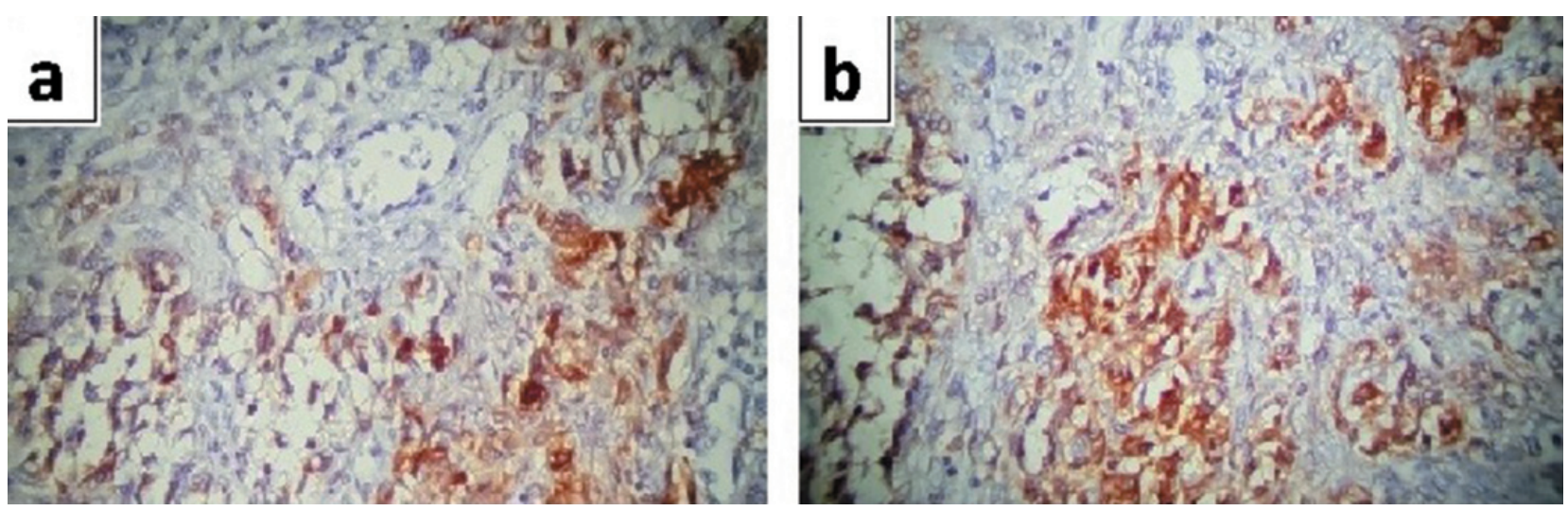

Figure 2. Calretinin positive tumor cells. b. CD99 positive tumor cells.

To best of our knowledge, 5 of the patients who had undergone hysterectomy and 4 of the patients who had fertility sparing surgery had recurrences $(2,4,6,7)$. Incomplete resection of the tumor can be one of the reasons for recurrences in patients who had fertility sparing surgery. Therefore, wide excision with enough clear margins such as in our case can be done in order to lower recurrence rates. Surgeons should also be cautious for surgical spill which may be the reason for recurrence in one patient (2).

Infiltrative border, vascular invasion, frequent mitotic figures, serosal rupture, stromal predominance and cytological atypia are found to be associated with recurrence (8). In another study, risk factors for recurrence were found to be pelvic pain at the time of diagnosis, tumor size $10 \mathrm{~cm}$ or greater, presence of cervical/extra-uterine disease and lymphovascular space invasion (4).

Conservative management can be an option for younger women who have fertility desire. It seems like it is an acceptable choice since the tumor has low malignant potential. More cases are needed to support the safety and outcome of fertility preserving treatment.

\section{References}

1. Clement PB, Scully RE. Uterine tumors resembling ovarian sex cord tumors. A clinicopathologic analysis of fourteen cases. Am J Clin Pathol 1976;66:512.

2. Schraag SM, Caduff R, Dedes KJ, Fink D, Schmidt AM. Uterine tumors resembling ovarian sex cord tumors - treatment, recurrence, pregnancy and brief review. Gynecol Oncol Rep 2017;19:53-56.
3. Jeong KH, Lee HN, Kim MK, Kim ML, Seong SJ, Shin E. Successful delivery after conservative resectoscopic surgery in a patient with a uterine tumor resembling ovarian sex cord tumor with myometrial invasion. Obstet Gynecol Sci 2015;58(5):418-422.

4. Blake EA, Sheridan TB, Wang KL, et al. Clinical characteristics and outcomes of uterine tumors resembling ovarian sex-cord tumors (UTROSCT): a systematic review of literature. Eur J Obstet Gynecol Reprod Biol 2014;181C:163-170.

5. De Franciscis P, Grauso F, Ambrosio D, Torella M, Messalli EM, Colacurci N. Conservative resectoscopic surgery, successful delivery, and 60 months of follow-up in a patient with endometrial stromal tumor with sex-cordlike differentiation. Case Rep Obstet Gynecol 5736865.

6. Liu CY, Shen Y, Zhao JG, Qu PP. Clinical experience of uterine tumors resembling ovarian sex cord tumors: a clinicopathological analysis of 6 cases. Int J Clin Exp Pathol 2015;8(4):4158-4164

7. Endo D, Todo Y, Okamoto K, Suzuki H. A case of recurrent group II uterine tumor resembling ovarian sex-cord tumors, against which two hormonal agents were ineffective. Taiwan J Obstet Gynecol 2016 Oct;55(5):751-3.

8. Pradhan D, Mohanty SK. Uterine tumors resembling ovarian sex cord tumors. Arch Pathol Lab Med 2013 Dec;137(12):1832-1836. 
